\title{
Review on the Major Failure Cases of Unlined Pressure Shafts/Tunnels of Norwegian Hydropower Projects
}

Dr. Krishna Kantha Panthi and Er. Chhatra Bahadur Basnet

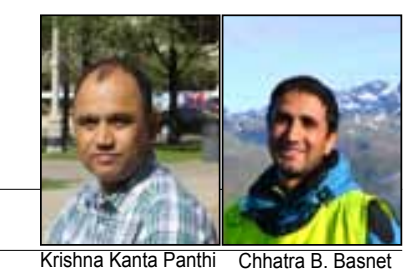

Abstract: The Norwegian hydropower industry has more than 100 years of experience in constructing the unlined pressure shafts and tunnels. Most of the hydropower projects have long waterway systems consisting unlined high pressure shafts, underground powerhouse cavern, headrace and tailrace tunnels. The maximum static head reached with unlined pressure shaft and pressure tunnel concept is 1047 meter, which is equivalent to almost $10.5 \mathrm{MPa}$. It is obvious that the rock mass in the periphery of unlined shafts and tunnels experience high hydrostatic pressure exerted by the flowing water discharge. Experienced gained from the construction and operation of these unlined pressure shafts and tunnels were useful to develop design criterion and principles applied here in the Scandinavia. This paper reviews some of the first attempts of the use of unlined pressure shaft and tunnel concepts, highlights major failure cases, reviews and evaluates the triggering factors for the failure and also discusses about the gradual development of design criterion for the unlined pressure shafts and tunnels. The authors consider this review is a first step in the upgrade on this innovative concept, which could be used in other geological and tectonic environment than of the Scandinavia, such as in the Himalaya.

Keywords: Unlined pressure shafts and tunnels, hydropower projects, Norway, Himalaya

\section{Introduction}

$\mathrm{T}$ he Norwegian hydropower industry has more than 100 years of experience in underground works. The typical layout of the hydropower scheme before 1940 s consisted horizontal headrace tunnel, penstock along the surface topography and powerhouse on the bottom of the valley. Certainly, there had been attempts in the early 1920 s to build underground pressure shafts (both steel lined and unlined) and underground powerhouse. The first such hydropower scheme with underground powerhouse was built in the year 1916. However, emphasis was given to keep all waterway system and powerhouses inside the mountain mainly after the completion of World War II. Today, according to Broch (2013), Norway has over 200 underground powerhouses and over $4200 \mathrm{~km}$ hydropower tunnels. Experiences gained in design, construction and operation of waterway system has led to the development of innovative ideas. One of these ideas is the application of unlined high pressure tunnels and shafts in hydropower schemes. Such tunnels and shafts were considered to be possible due to the favorable engineering geological and tectonic conditions that persist in the Scandinavia. It is estimated that over $95 \%$ of the waterway length of Norwegian hydropower schemes are left unlined (Johansen, 1984; Panthi, 2014).

Geologically, Norway is typically considered as a hard rock province and approximately two thirds of the country is situated in the Precambrian rocks, which includes gneisses (the most dominant rock type), granites, gabbros and quartzites. In addition, about one third of the landscape is made up of rocks of Cambro-Silurian age (mainly Caledonian mountain range) consisting different mix of rock types such as gneisses, schists, phyllites, greenstones and marbles of varying degree of metamorphism as well as granites, gabbros, sandstones, shales, dolomites and limestones (Johansen, 1984). It is worthy to note here that most of the waterway systems of Norwegian hydropower schemes are also situated in the rock mass of this Caledonian mountain range. The typical feature of Norwegian landscape is that the last deglaciation left the rock surface without any appreciable weathered material in the top of the surface but, there is always a tendency of a frequent jointing in the rock mass near the surfaces. This condition may lead higher permeability of rock mass to a depth ranging from 5 to 40 meters (Selmer-Olsen, 1969). On the other hand, more stabilized tectonic movement (relatively less tectonic movement in comparison to other mountainous regions) and the deglaciation led to experience high horizontal stress, which helped to increase confinement in the rock mass even near surface.

The success history of the operation of unlined pressure shafts and tunnels in Norway is almost 99 percent and have experienced very little stability problems over the past. However, there have been exceptions where problems were registered during the initial phase of the development of unlined concepts. These project cases were considered as failure cases and detail study of the failure were carried out and the lesson learned from the failure were helpful in developing certain design principle and criterions for unlined high pressure tunnels and shafts. This paper studies these early incidences of failures, summarizes common failure problems and tests developed design criterions after the 1960 s to the reviewed cases. Recommendations are also suggested for the accepted limit of specific leakage through unlined pressure shafts and tunnels.

History of Unlined Pressure Shafts and Tunnels An attempt to use unlined pressure shaft and tunnel in hydropower projects started early 1920 in Norway (Vogt, 1922). Four projects were implemented around this time. Three out of these four projects had problems during initial water filling and these 
problems were solved by extending the penstock pipe and grouting. All four projects were designed with low pressure headrace tunnel, unlined inclined pressure shafts, and horizontal penstock tunnel as waterway system connecting the powerhouse located at surface like as shown in Figure 1a. Although three out of four hydropower schemes with unlined pressure shafts were operating perfectly after initial problems were fixed, it took almost 40 years to beat the world record of static water head of $152 \mathrm{~m}$ with unlined high pressure shaft of Svelgen hydropower project (Figure 2). The Tafjord $\mathrm{K}_{3}$ hydropower project with a static head of $286 \mathrm{~m}$ was the one to beat this record, which was successfully put into operation in 1958 (Broch, 1982). After the construction of this project the hydropower industry in Norway had a new confidence in the application of unlined pressure shafts. Most of the hydropower projects built between 1930 and 1955 (before the Tafjort $\mathrm{K}_{3}$ ), however, had used the design principle of unlined low pressure headrace tunnel, penstock lined high pressure shafts and underground powerhouse. The general layout design used for the hydropower schemes after Tafjort $\mathrm{K}_{3}$ is shown in Figure $1 \mathrm{~b}$. This type of design uses very limited length of steel lining near the powerhouse (mostly not exceeding $75 \mathrm{~m}$ ) in order to avoid the leakage from unlined pressure shaft to the underground powerhouse cavern.

In areas where topography restricted the complete of the turbines. However, at the Driva hydropower project that came in operation in 1973 had difficulties to arrange vented surge chamber due to extremely steep and difficult topographic condition, where it was not possible to build an access road to reach the intermediate construction adit and top of the surge shaft. As a result, an innovative attempt was made to implement Air Cushion Surge Chamber (Buen, 1984, Rathe, 1975; Selmer-Olsen, 1974).

The Air Cushion Surge Chamber is an unlined underground cavern built upstream of the penstock shaft near powerhouse cavern where compressed air is filled to make a cushion against the upsurge pressure like as shown in Figure 1d. Such an innovation gave solution against the conventional vented surgeshafts if topographic conditions found difficult. Today, Norway has 10 hydropower schemes where Air Cushion Surge Cambers are used to control the upsurge oscillation caused by the sudden stoppage of the power plant. The benefit of this solution is that a hydropower schemes can avoid an inclined or vertical shaft. Instead, a long unlined high pressure tunnel may connect the intake with underground powerhouse through a very short penstock shaft/tunnel near the powerhouse. At present, Norway has many unlined pressure tunnels and shafts of varying static heads with maximum static water head of $1047 \mathrm{~m}$ at Nye
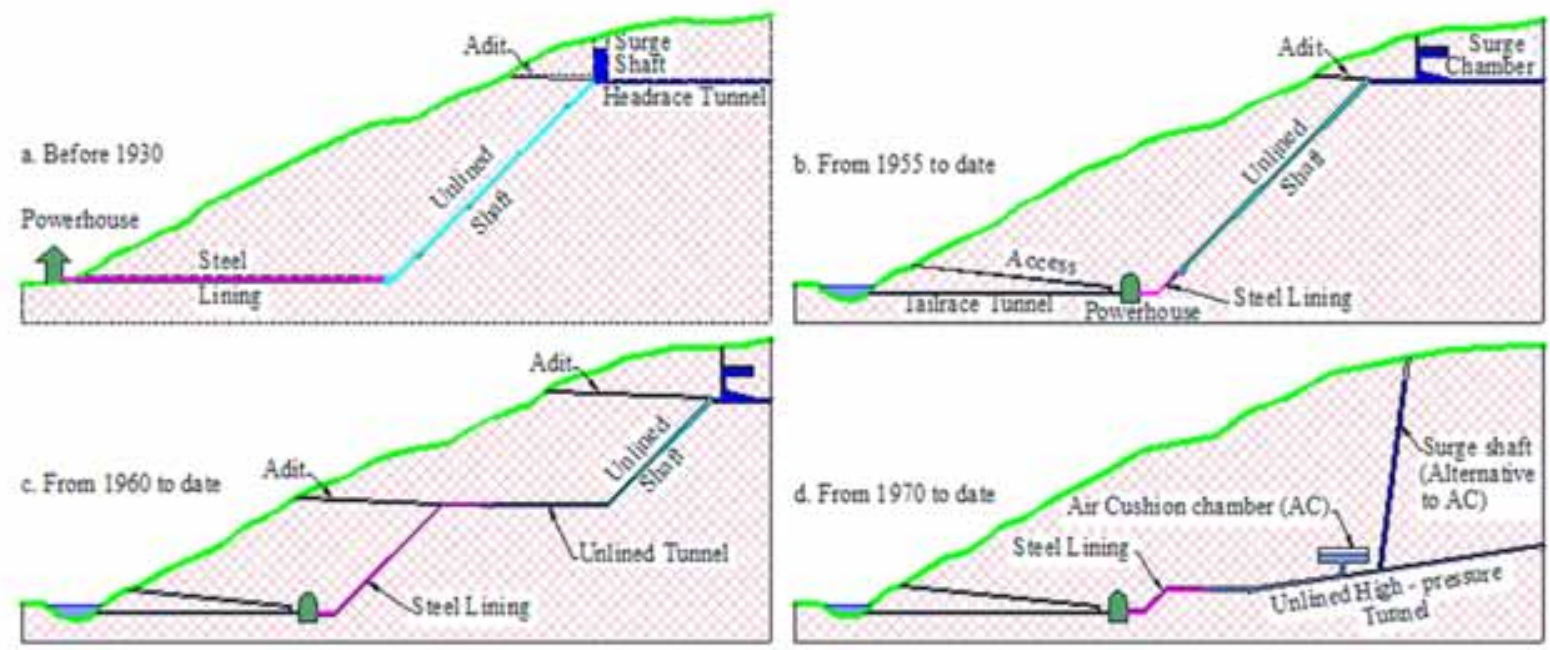

Figure 1: Development of unlined high pressure shafts and tunnels in Norway since 1920

use of unlined high pressure shaft all the way from near the underground powerhouse, an layout arrangement consisting steel lined lower shaft and part of the horizontal pressure tunnel downstream of unlined upper pressure shafts and headrace tunnel like as shown in Figure 1c became common hydropower design solutions after around 1960.

Quite a lot of experience was gained in the operation of high pressure unlined shafts and tunnels with up to static water head of $475 \mathrm{~m}$ by 1970 at Hovatn hydropower project. Until the beginning of 1970 , all the hydropower schemes consisted the vented surge chamber to dampen the oscillation waves (upsurge waves) produced due to sudden stoppage
Tyin hydropower project, which is successfully came in operation in 2004 (Figure 2).

\section{Major Failure Cases}

Most of the unlined pressure shafts and tunnels are successfully operated with no long-term instability problems excluding few exceptions, which were the basis for the development of design principles and criterions. The Herlandsfoss was the first hydropower scheme built in 1919 to use unlined pressure shaft concept in Norway and followed by Skar and Svelgen built in the years 1920 and 1921. Mixed experience was gained from these three projects with Skar completely failed and other two were possible to bring in operation after the appropriate mitigation measures applied. Even though, all unlined high pressure shafts 
and tunnels follow the developed design principles and criterion, still there are cases of failures even in modern time where further investigations were needed with substantial mitigation measures applied after the first water filling. Some of the major failure cases of shafts and tunnels with rock type and construction completion year are presented in Table 1 below. filling in the waterway system. The failure occurred at the unlined pressure shaft of Byrte hydropower project in 1968 was mainly related to the unfavorably oriented fracture system and faults. The hydraulic splitting at the clay filled faults had occurred after the water filling had reached its maximum hydrostatic pressure. Similarly, hydraulic splitting occurred at the unlined pressure tunnel of Åskåra hydropower project after the system reached hydrostatic head of approximately $200 \mathrm{~m}$ (Broch, 1982). The splitting made it possible to open the pre-existing steeply dipping joints in the rock mass with the strike parallel to the steep valley side slope. Bjerka hydropower project also experienced leakage through the pressure tunnel in 1971. The leakage was registered at a distance about one kilometer away from the pressure tunnel. This example has demonstrated that unfavorably oriented joint systems filled with calcite clay, fine silt and sand may further be opened by hydraulic splitting and forming a leakage channel that may reach long away from the unlined pressure shafts and tunnels. A recent case

Table 1: Failure of unlined pressure shafts and tunnels in Norway (Broch, 1982; Selmer-Olsen, 1985)

As shown in Table 1 above the first failure case was Herlandfoss project where the unlined pressure tunnel was partly failed and considerable leakage occurred and steel lining was further extended as a final solution. At Skar, although the pressure shaft and tunnel was aligned through very competent granitic gneiss, the waterway system mostly failed excluding the upper most part. This is mainly due to very low rock cover of about $22 \mathrm{~m}$ only with a plant having static water head of $116 \mathrm{~m}$ (Broch, 1982). At Svelgen, the leakage was observed during the first filling of the pressure shaft. A short part of the shaft was then lined with concrete and cement grouted.

According to Buen and Palmstrom (1982) in the years 1968, 1970 and 1971, during filling up of water way system, unforeseen deformation and water leakages had occurred in different hydropower plants, which were built using proven tunneling technologies and design knowledge base (Table 1). The leakage occurred mostly after one to three days of the water of leakage through the pressure tunnel is at Holsbru hydropower project, which came in operation in 2012. The measured leakage at a v-notch installed in the drainage channel of the access road was about $22 \mathrm{l} / \mathrm{s}$.

Herlandfoss project is located in Osterøy commune in Hordaland of Norway. The project was built in 1919 and is the first hydropower project to implement unlined pressure shaft concept in Norway. The project has a design discharge of $6 \mathrm{~m} 3 / \mathrm{s}$, maximum gross head is of $140 \mathrm{~m}$ and an installed capacity of 12 MW. This power plant was upgraded in 1995 with a slightly increased installed capacity to $13.8 \mathrm{MW}$. The project has $1400 \mathrm{~m}$ long headrace tunnel, surge shaft, inclined unlined shaft dipping approximately at 40 degrees, $175 \mathrm{~m}$ long horizontal penstock tunnel near the powerhouse located at surface (Figure 3).

As indicated in Figure 3, the main rock types in the project were registered as hornblende schist and mica schist. The schist had foliation strike NW-SE with dip of about 500 SW (Vogt, 1922). The unlined

\section{Herlandsfoss}


shaft was aligned almost parallel with the foliation plane. Hornblende schist was found to be massive and of good quality compared with the mica schist. A band of talcose mica schist passed through the south west side of downstream valley side, which was highly fractured. Mica schist between chainage $55 \mathrm{~m}$ and 98 $\mathrm{m}$ was observed to be highly schistose and rich with chlorite and muscovite. The schistosity was found to be extreme and even fingers could separate the fresh rock mass. Hornblende schist has some joints crosscutting across the foliation planes (Selmer-Olsen. distance of about $50 \mathrm{~m}$ from the cone area.

The observed leakage at one particular location at surface was about $300 \mathrm{l} / \mathrm{s}$. As a remedial measure, reinforced concrete lining with a minimum thickness of $50 \mathrm{~cm}$ was carried out covering $60 \mathrm{~m}$ more pressure tunnel. Second water filling was made, however, after two months of power plant operation, rapid increase in leakages was observed once again at the surface. The waterway system was drained again and inspection was carried out. Many open cracks with an opening of up to $20 \mathrm{~cm}$ were found in reinforced concrete lining between chainage $70 \mathrm{~m}$ to $79 \mathrm{~m}$ covering both tunnel walls near the spring line. SelmerOlsen (1969) interpreted this incident in such a way that the rock mass over the tunnel had been lifted during first cracking and then deformed downward after water way was drained. Finally, decision was made to extend penstock all the way up to the bottom of the inclined pressure

Figure 3: The Herlandsfoss hydroelectric project, in operation since 1919 (Redrawn from Vogt, 1922)

1969).

Initially, the steel penstock pipe was installed to cover only the first $50 \mathrm{~m}$ long section from the turbine. A concrete plug was installed at the cone section as shown in Figure 3. Vogt (1922) reported that water inflow was observed from chainage 92 $\mathrm{m}$ to $94 \mathrm{~m}$ during construction. Concrete lining was used as mitigation measure at this tunnel stretch and rest of the $150 \mathrm{~m}$ horizontal pressure tunnel was kept unlined all the way up to the bottom of the shaft (Figure 3). A minor leakage was observed at the outer part of pressure tunnel during first water filling with a static water head reaching $123 \mathrm{~m}$. After five hours of full hydrostatic pressure, considerable amount of water leaked from the upstream of the cone area and leakage channel reached all the way to the surface over the $50 \mathrm{~m}$ chainage. The waterway system was drained and inspection was carried out. It was observed that considerable amount of inflow was coming back at chainage $98 \mathrm{~m}$. This demonstrated on the extent of hydraulic splitting occurred in the tunnel after water filling. This splitting led to extend existing joints in the rock mass and also new fractures were developed along the spring line of unlined pressure tunnel over afrom Vogt, 1922) shaft up to the point B as indicated in Figure 3. The third water filling was a complete success with no significant water leakage registered and this project become the first unlined pressure shaft of Norway.

\section{Svelgen}

Svelgen hydropower project is located in Bremanger municipality in Sogn \& Fjordane county of Norway. It was built in 1921 and has $1600 \mathrm{~m}$ long horizontal headrace tunnel, surge shaft, unlined pressure shafts and pressure tunnel, two penstock lined tunnels and a penstock lined shaft and a powerhouse located at the surface. The project was designed with a design discharge of $6.5 \mathrm{~m}^{3} / \mathrm{sec}, 225 \mathrm{~m}$ maximum gross head and $12 \mathrm{MW}$ installed capacity. Maximum static head at the level of unlined pressure tunnel (Figure 4) is

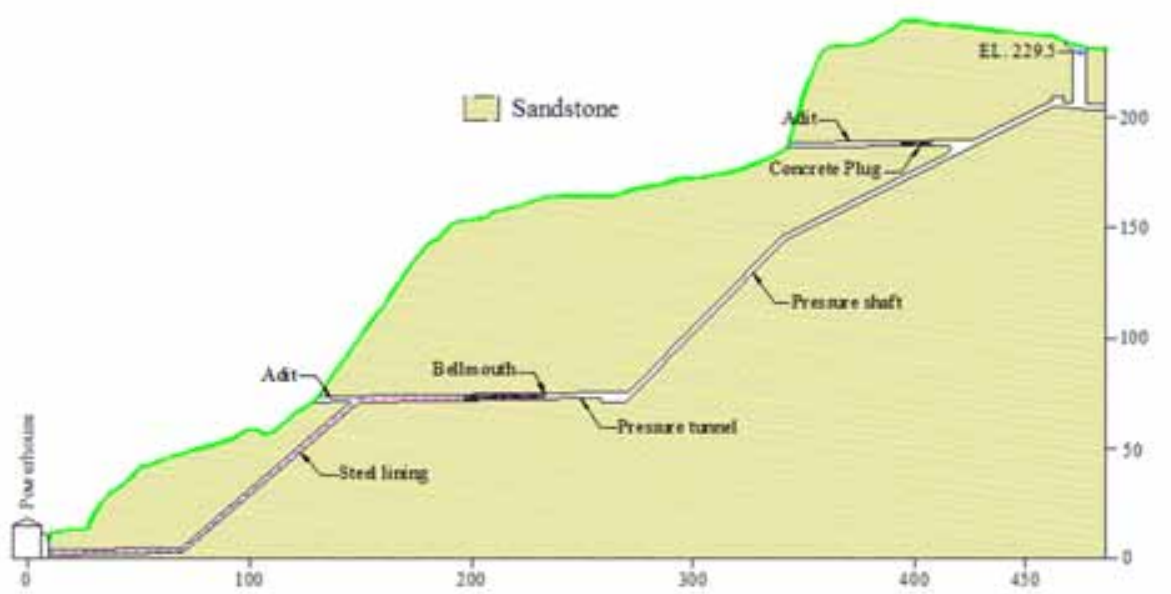

Figure 4: The pressure tunnels and shafts arrangement at Svelgen hydropower project (Redrawn 
about $152 \mathrm{~m}$.

The rock formation at the project area belongs to Devonian sandstone. The brown-green colored sandstone is fine grained and has dominating mineral quartz with other minerals such as feldspar and muscovite/chlorite. Sandstone is slightly metamorphosed with varying degree of schistosity and may therefore be categorized as meta-sandstone. Rock mass in the project area consisted distinct two joint sets representing bedding planes and cross joints. These two joins sets cross almost perpendicular to each other. At the surface topography, the joints are weathered and filled with silt and clay. Bedding planes strike at $\mathrm{N} 25^{\circ}-40^{\circ} \mathrm{E}$ and gently dip with $24^{\circ}-$ $29^{\circ} \mathrm{SE}$. The steeply dipping cross joints have an average orientation of $\mathrm{N} 135^{\circ} \mathrm{E}$ and make an angle of $60^{\circ}-65^{\circ}$ with bedding planes.

Since the fine grained sandstone has in general low degree of porosity, the leakage risk was always through the joint system; from both gently dipping bedding joints and steeply dipping cross-joints. During excavation, very little inflow in both tunnels and shafts was registered. Test water filling was carried out until the elevation of 223 masl. The pressure tunnels and shafts were filled in four hours period and rest of the headrace tunnel was filled in 5 days period. To check the leakage through the unlined waterway system, inlet gate was closed for two days and water level was sinked to 160 masl from the maximum elevation of 223 masl (Vogt, 1922). Water loss from the waterway system was calculated to about $70 \mathrm{l} / \mathrm{s}$. A short part of the pressure tunnel was concrete lined and cement grouted. After then the waterway system functioned normal and no as such failure reported.

\section{Byrte}

Byrte project is situated in Tokke commune in Telemark county of Norway. It was built in 1968 with 20 MW installed capacity. The project has low pressure headrace tunnel, surge shaft, unlined pressure shaft (6oo inclination), about $80 \mathrm{~m}$ long steel lined horizontal tunnel, underground powerhouse and about 200m long tailrace tunnel. The project was designed with a design discharge of $8 \mathrm{~m}^{3} / \mathrm{sec}$ and with maximum gross head of $295 \mathrm{~m}$. Main rock type in the project is granitic gneiss. The rock mass consists several systems of joint sets dipping between 550 and 700, and minor faults with strike approximately parallel to the valley side slope (Selmer-Olsen, 1969). There is also a wide clay-filled fault at Byrte Lake, which is called 'Byrte Fault' (Figure 5).

According to Selmer-Olsen (1969), the power plant was run for below $280 \mathrm{~m}$ water head for the initial period of two months. During this period, insignificant leakage was registered. However, once the static head was elevated, it was observed that the leakage was increasing slowly but steadily. Once the operation crew by mistake increased the static head to $300 \mathrm{~m}$, hydraulic splitting occurred in the rock mass and the leakage increased very rapidly. Many cracks were observed in the rock mass both in the shaft and powerhouse cavern. It was necessary to pump out the leaked water from the power station. In addition to the leakage at the underground powerhouse cavern, several springs were also appeared at the surface topography indicating considerable leakage through the rock mass. The overall leakage from this unlined pressure shaft was estimated to more than $1 \mathrm{~m} 3 / \mathrm{s}$ 
rock mass below this crushed zone is less fractured, massive and impermeable. On the other hand, the rock mass above this zone was found to be jointed. In addition to the bedding planes and crushed zones along the bedding planes, there is one more distinct joint set in the area. This cross joint has a strike orientation of NNW-SSE and steeply dipping towards

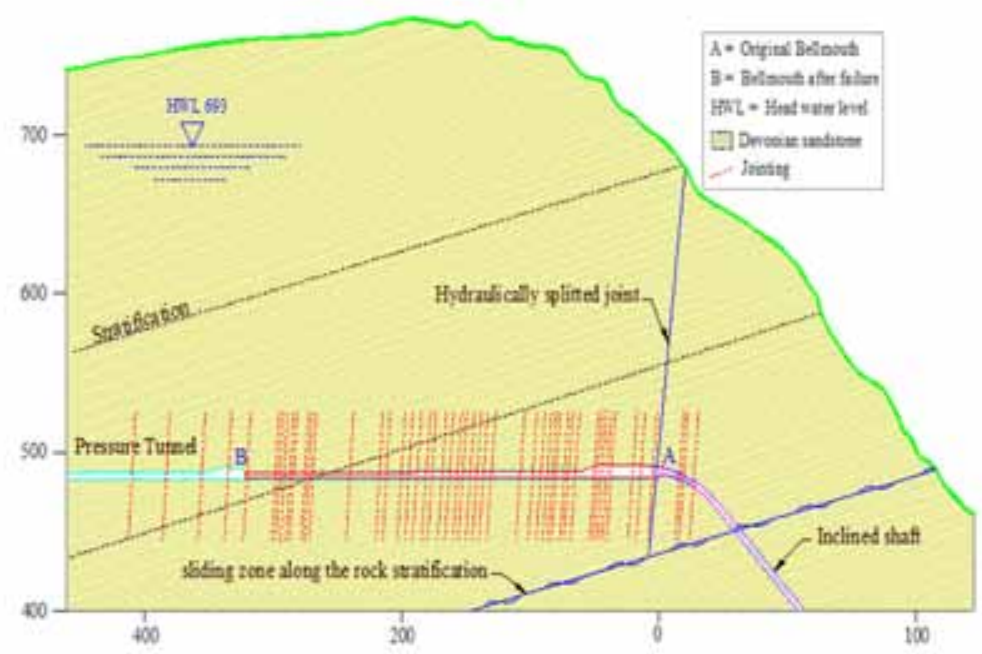

NW (Figure 6).

Figure 6: Section through pressure tunnel of Åskåra power plant (Redrawn from Bergh-Christensen, 1975)

In the first stage of project construction at about $173 \mathrm{~m}$ chainage (Figure 6), considerable water inflow into the tunnel was registered and it was sealed with cement grouting. This inflow indicated possibility of leakage from the pressure tunnel during operation. Initially the pressure tunnel was kept unlined up to the point A in Figure 6. The first water filling was carried out in the waterway system achieving full hydrostatic head of $690 \mathrm{~m}$. The filling process was gradual until the unlined pressure tunnel reached to a hydrostatic pressure of $194 \mathrm{~m}$ and filling of remaining part was fairly quick. Leakage was observed at the western valley slope of the mountain topography immediately after the water filling was completed. The next day, large leakage of about $1.0 \mathrm{~m}^{3} / \mathrm{sec}$ was registered on the same place indicating complete failure at the downstream end of the unlined pressure tunnel. The waterway system was drained and inspection was carried out. During inspection it was observed that the cross joints were opened by about $3-4 \mathrm{~cm}$ between the tunnel section A and B (Figure 6). The opening in the joints clearly demonstrated the occurrence of hydraulic splitting. Finally, steel lining was extended up to point B. After this modification, the power plant is being operated successfully.

\section{Bjerka}

The 20 MW Bjerka hydropower project, which came in operation in 1972, is located in Leirskardalen valley in Hemnes kommune in Nordland. It has a gross head of $370 \mathrm{~m}$ and consists $4.5 \mathrm{~km}$ unlined pressure tunnel with maximum water pressure of $72 \mathrm{~m}$, $900 \mathrm{~m}$ long surface penstock and a surface powerhouse. Main rock type along the headrace tunnel was registered as massive granitic gneiss. The rock mass had two dominating joint sets. The foliation joints strike approximately parallel to the hill side slope and dip about $10-20^{\circ}$ towards the valley slope. Cross joints are also dipping towards the valley side slope but the dip angle is steep. The cross joints intersect the tunnel axis almost perpendicularly (Figure 7). The cross joints had spacing ranging from 5 to 10 $\mathrm{m}$ with joint opening ranging from 1 to $10 \mathrm{~mm}$, which were found filled with clay and silt material (Valstad, 1981). The filling material observed was relatively compacted but easy to erode or wash away.

Initially, the penstock cone was placed at about $100 \mathrm{~m}$ from the tunnel portal at point $\mathrm{A}$ as shown in Figure 7. Three of the exposed steeply dipping cross joints upstream of the cone area were found to be open and these joints were filled with plumb concrete as a remedial measure during construction. The filling of the waterway system was carried out. Shortly after the water filling with the maximum static water head of $72 \mathrm{~m}$ at point A, small leakage was observed downstream of the cone plug. As a surprise, after four days of operation, large leakage was registered at the bottom of the valley slope just above the power station. The power plant was closed immediately. After 30 minutes of stoppage the water level reduced by $23 \mathrm{~m}$. This reduced water level indicates a leakage of approximately $1.2 \mathrm{~m}^{3} / \mathrm{sec}$. Tunnel inspection was carried out after the drainage. It was observed that the pre- existing joints immediately upstream of concrete plug were opened by approximately $20 \mathrm{~mm}$ in walls and $53 \mathrm{~mm}$ in the floor (Valstad, 1981). The opening in the joints clearly indicated that there had been hydraulic splitting, which led to the shift of valley side. As a remedial measure, the penstock pipe was extended further by about $80 \mathrm{~m}$ to point B (Figure 7). The water way system was filled once again with

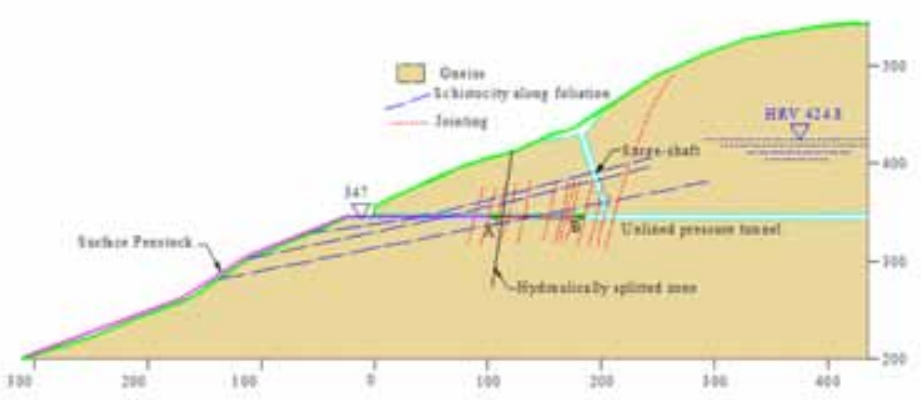

Figure 7: Geological details of the outer end of Bjerka unlined pressure tunnel (Redrawn from Valstad, 1981)

care and well planned monitoring. The filling was successful and no significant leakage was registered.

\section{Comparison of Failures}


It would be useful to compare these failure cases based on geologic formation, rock types, jointing conditions, faulting and static head experienced by each case. Such comparison will help build concepts in the use of unlined pressure tunnel systems in areas out of the Scandinavia. It is highlighted here that no matter what geological formation is, the real challenge in the use of unlined pressure tunnel is associated to the potential hydraulic splitting, which may led to the leakage out of the pressure tunnel system.

\section{Engineering Geological Conditions}

All six cases, which experienced partial collapse after first water filling, are situated in different geological formation. However, there is considerable commonness when it comes to the jointing conditions. using following Rule of Thumb;

$$
h>c \cdot H
$$

Where; $h$ is minimum required rock cover over the shaft alignment, $\mathrm{H}$ is hydrostatic head acting over the shaft alignment and $\mathrm{c}$ is and constant that has a value of 0.6 for valley sides with inclinations up to $35^{\circ}$ and 1.0 for valley sides slope exceeding $35^{\circ}$. Note that in Norway the inclinations of the unlined shaft varied between $31^{\circ}$ and $47^{\circ}$ with $45^{\circ}$ as the most common inclination angle.

After the failure of unlined pressure shaft at Byrte in 1968 where the pressure shaft had an inclination of $60^{\circ}$, the Rule of Thumb expressed by Equation 1 was upgraded as following (Broch, 1984);

\begin{tabular}{|c|c|c|c|c|}
\hline Project & $\begin{array}{c}\text { Geology and rock } \\
\text { types }\end{array}$ & Jointing & Joint infilling & $\begin{array}{c}\text { Fault and weakness } \\
\text { zones }\end{array}$ \\
\hline Herlandsfoss & $\begin{array}{l}\text { Cambro Silurian } \\
\text { Hornblende Schist } \\
\text { and mica schist }\end{array}$ & $\begin{array}{l}\text { Two joint sets. Intersecting } \\
\text { joints consisting foliation joint } \\
\text { and cross- joints }\end{array}$ & $\begin{array}{l}\text { Mica schist is highly schistose } \\
\text { and rich in chlorite and } \\
\text { muscovite at the failure } \\
\text { location }\end{array}$ & $\begin{array}{l}\text { The failure occurred } \\
\text { through the band of } \\
\text { highly schistose rock } \\
\text { mass representing a fault }\end{array}$ \\
\hline Skar & $\begin{array}{l}\text { Precambrian Granitic } \\
\text { gneiss }\end{array}$ & $\begin{array}{l}\text { Foliation joints and random } \\
\text { joints in all directions }\end{array}$ & $\begin{array}{l}\text { Schistosity formation along } \\
\text { the foliation joint and } \\
\text { occasional hornblende } \\
\text { mineral coating }\end{array}$ & No nearby fault exist \\
\hline Svelgen & Devonian Sandstone & $\begin{array}{l}\text { Intersecting gently dipping } \\
\text { bedding joints and cross } \\
\text { joints almost perpendicular to } \\
\text { the tunnel alignment }\end{array}$ & $\begin{array}{l}\text { Altered joints either open or } \\
\text { filled with silt and clay }\end{array}$ & No nearby fault zones \\
\hline Byrte & $\begin{array}{l}\text { Precambrian Granitic } \\
\text { gneiss }\end{array}$ & $\begin{array}{l}\text { Several systems of joints and } \\
\text { some are steeply dipping }\end{array}$ & Joints are silt and clay filled & $\begin{array}{l}\text { Two long persisting clay } \\
\text { filled faults parallel to } \\
\text { the valley side slope. } \\
\text { One crosses the pressure } \\
\text { shaft and another DS of } \\
\text { powerhouse }\end{array}$ \\
\hline Åskåra & Devonian Sandstone & $\begin{array}{l}\text { Two distinct joint sets } \\
\text { consisting foliation and steeply } \\
\text { dipping cross joints }\end{array}$ & $\begin{array}{l}\text { Cross joints have opening } \\
5-20 \mathrm{~mm} \text { and are filled with } \\
\text { silt and clay }\end{array}$ & $\begin{array}{l}\text { A fault separates } \\
\text { fractured rock mass with } \\
\text { massive one }\end{array}$ \\
\hline Bjerka & $\begin{array}{l}\text { Cambro-Silurian } \\
\text { Gneiss }\end{array}$ & $\begin{array}{l}\text { Two joint sets. Widely spaced } \\
\text { foliation joints and steeply } \\
\text { dipping cross joints. }\end{array}$ & $\begin{array}{l}\text { The cross joints that are } \\
\text { perpendicular to the tunnel } \\
\text { alignment have } 1-10 \mathrm{~mm} \\
\text { opening and filled with silt } \\
\text { and clay }\end{array}$ & No fault zone \\
\hline
\end{tabular}

Table 2: Comparison of failures based on geology, rock types, jointing, joint filling conditions and faulting

In Table 2 below, one can find the highlights on the geological formations, rock types, jointing and their infilling conditions, and nearby faults if any.

As seen in Table 2, all six failure cases have major two joint sets with one of the joint set steeply dipping and unfavorably orientated. In addition, the joints are filled with silt and clay mineral coating, which could be washed easily increasing the permeability. Permeable joints form leakage paths making it easy for the pressure built up. The nearby faults facilitate this process even further.

\section{Assessment with Design Criterion}

According to Broch (1982), unlined pressure shafts and tunnels built in the 1950 os and 1960 s are designed

$$
h>\frac{H}{\gamma \cos \alpha}
$$

$\gamma=\frac{\gamma_{r}}{\gamma_{w}}$

Where; $\gamma$ is bulk density, $\gamma w$ is the density of water, $\gamma r$ is the density of the rock type and $\alpha$ is the inclination of the shaft in degrees.

The above design criterion was used in the design of unlined shafts in Norway until the failure at Åskåra in 1973. This failure led establishment of a new concept that also considers shortest perpendicular distance (L) from the valley inclination line with an inclination angle of $\beta$ in degrees. In addition to the 
criterion expressed by Equation 2, a new Rule of Thumb explained by Equation 4 was introduced;

$L>\frac{H}{\gamma \cos \beta}$

Since then both Equation 2 and Equation 4 are considered as the State-ofArt Norwegian design criterion for unlined pressure shafts and tunnels. In addition to these two criterion consistent use of both $2 \mathrm{D}$ and $3 \mathrm{D}$ finite element analysis to check stress state along the alignment are common today.

It would be of great interest to check whether the cases described above fulfill the design criterions sent by Equation 2 and 4. While doing so, a correction of valley side slope for protruding noses as recommended by Broch (1984) has been applied while defining the valley side slope angle and measuring the available shortest distance (L'). The details of the calculation including available factor of safety are presented in Table 3 .

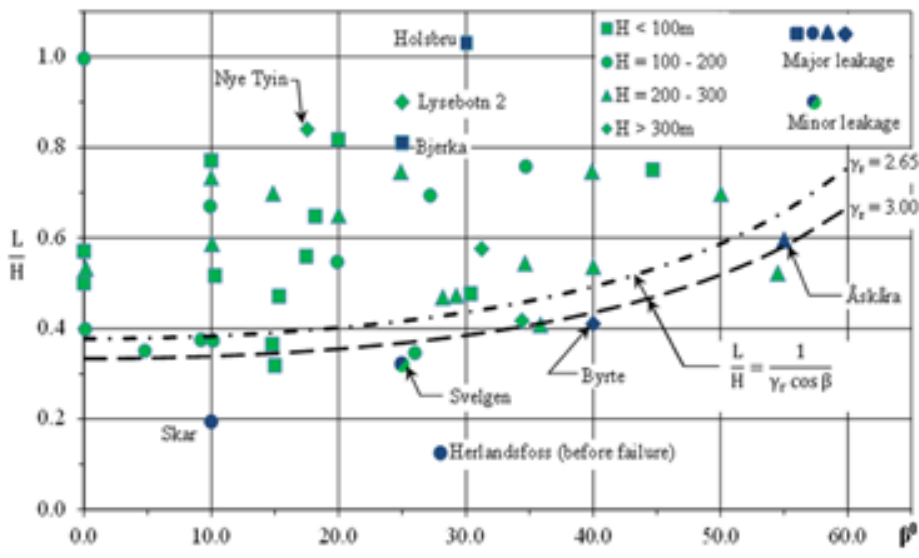

Figure. 9: Unlined pressure shafts/tunnels in valley side with various inclinations, $\beta$. Updated from Broch (1982).

insufficient shortest distance from the side slope for Åskåra Project (Figure 8). It is, therefore, obvious that leakage occurred through these pressure shafts and tunnels are mainly due to hydraulic splitting. The leakage occurred at Bjerka seems more linked to the pre-existing open joints. The detail assessments

\begin{tabular}{|c|c|c|c|c|c|c|c|c|c|c|c|}
\hline Project & $\mathrm{Hm}$ & $\begin{array}{c}\mathrm{yr} \\
\text { ton/ } \\
\mathrm{m}^{3}\end{array}$ & $h^{\prime} \mathbf{m}$ & $\underset{\text { Deg }}{\mathbf{a}}$ & $\begin{array}{c}\beta \\
\text { Deg }\end{array}$ & L'm & L'/H & $\begin{array}{c}\text { Required } \\
h \text { as per } \\
\text { Eq. } 2 \mathrm{~m}\end{array}$ & $\begin{array}{l}\text { Required } \\
L \text { as per } \\
\text { Eq.4m }\end{array}$ & $\begin{array}{l}\text { Factor of safety } \\
\text { for vertical } \\
\text { rock cover } \\
\left(\mathbf{F}=\mathbf{h}^{\prime} / \mathbf{h}\right)\end{array}$ & $\begin{array}{c}\text { Factor } \\
\text { of safety } \\
\text { for side } \\
\text { distance } \\
\left(F=L^{\prime} / L\right)\end{array}$ \\
\hline Herlandsfoss & 136 & 3.1 & 19 & 0 & 28 & 17 & 0.13 & 43.87 & 49.69 & 0.43 & 0.34 \\
\hline Skar & 129 & 2.65 & 30 & 8 & 10 & 25 & 0.19 & 49.16 & 49.43 & 0.61 & 0.51 \\
\hline Svelgen & 152 & 2.65 & 54 & 0 & 25 & 48 & 0.32 & 57.36 & 63.29 & 0.94 & 0.76 \\
\hline Byrte & 303 & 2.65 & 200 & 60 & 40 & 125 & 0.41 & 228.68 & 149.26 & 0.87 & 0.84 \\
\hline Åskåra & 210 & 2.65 & 200 & 0 & 55 & 125 & 0.60 & 79.25 & 138.16 & 2.52 & 0.90 \\
\hline Bjerka & 72 & 2.65 & 61 & 0 & 25 & 58 & 0.81 & 27.17 & 29.98 & 2.25 & 1.93 \\
\hline Holsbru & 63 & 2.65 & 76 & 0 & 30 & 65 & 1.03 & 23.77 & 27.45 & 3.20 & 2.37 \\
\hline
\end{tabular}

Table 3: Comparison of failures based on geology, rock types, jointing, joint filling conditions and faulting

As can be seen in Table 3, the factor of safety was found to be less than 1.3 as specified by Benson (1989) for both vertical rock cover and shortest distance from the valley side slope for projects Herlandsfoss, Skar, Svelgen and Byrte. Even though, the factor of safety for vertical rock cover is fulfilled, there exists

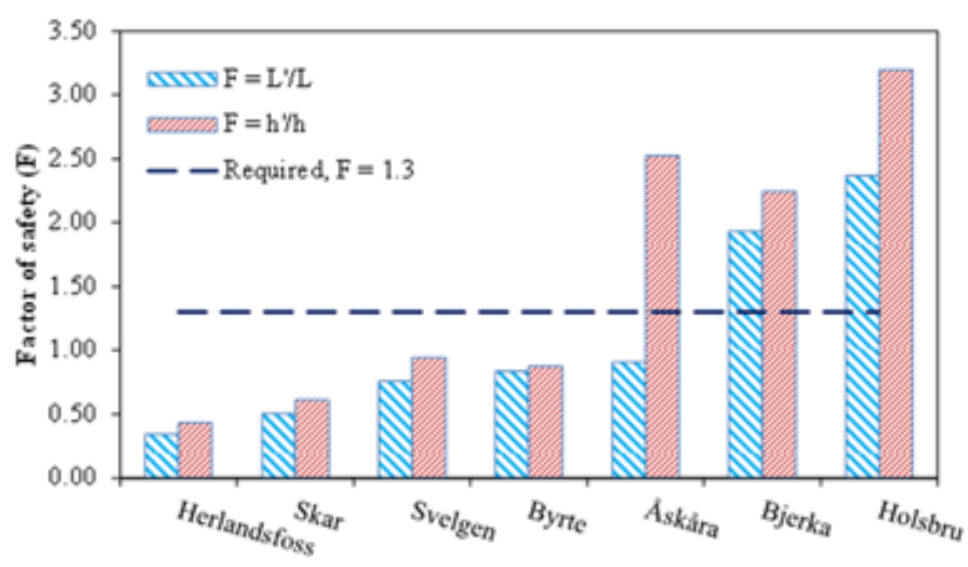

Figure 8: Factor of safety against vertical cover and valley side distance. are underway on the existing joint condition of the Holsbru project.

Five cases not fulfilling the design criterion for shortest distance were included in a chart presented by Broch (1982) (Figure 9). As can be seen, all projects are well below two dotted lines excluding Bjerka and Holsbru projects, which fulfilled the criterion but still substantial leakage occurred.

\section{Discussions}

The above review clearly indicates that in addition to the vertical rock cover $(\mathrm{h})$ and shortest distance (L) criterion defined by Equation 2 and 4, it is equally important that other expects of engineering geological environment and in-situ stress condition must be assessed to achieve safe design for unlined pressure shafts and tunnels. The leakage through the pressure shafts and tunnels not only occurs due to hydraulic splitting but also based on the 


\begin{tabular}{|c|c|c|l|}
\hline $\begin{array}{c}\text { Leakage } \\
\text { class (LC) }\end{array}$ & Class description & $\begin{array}{c}\text { Specific leakage (q) in } \\
\text { lit/min/m tunnel }\end{array}$ & \multicolumn{1}{|c|}{ Remarks } \\
\hline LC I & In significant leakage & $<1$ & $\begin{array}{l}\text { In general, no remedial measure needed. Monitoring on the } \\
\text { intensity of leakage over the time is required. }\end{array}$ \\
\hline LC II & Minor leakage & $1-1.5$ & $\begin{array}{l}\text { No remedial measure until unless there is a concentration of } \\
\text { leakage in one particular location. Monitoring on the intensity } \\
\text { of leakage over the time is required. }\end{array}$ \\
\hline LC III & Medium leakage & $1.5-2.0$ & $\begin{array}{l}\text { Identify areas from where major leakage is occurring and } \\
\text { decide the remedial measures to be taken. Continue monitoring } \\
\text { on the intensity of leakage over the time. }\end{array}$ \\
\hline LC IV & Major leakage & $2.0-5.0$ & $\begin{array}{l}\text { Identify areas from where major leakage is occurring. Access } \\
\text { the damage and make strategy for remedial measures. Re } \\
\text { assessment on the design may be needed. }\end{array}$ \\
\hline LC V & Excessive leakage & $>5.0$ & $\begin{array}{l}\text { Complete design failure. Permanent lining solutions must be } \\
\text { adopted. }\end{array}$ \\
\hline
\end{tabular}

Table 4. Leakage classification categories with respect to specific leakage

intensity of pre-existing joints in the rock mass and joint filling conditions.

In Norway, test water filling along the waterway system is first carried out to check whether leakage through unlined pressure shafts and tunnels is within acceptable limit of not. The extent of water leakage through unlined shafts and tunnels will then determine on what type of remedial measure be taken. However, amount of discharge that should be permitted to be leak through the rock mass has always been the matter of discussions and debate. One should note that each hydropower project is unique in itself and therefore shall be assessed individually on the basis of risk on long-term stability, loss of revenue caused by the leaked water and cost required to control the leakage. Based on the past experience and evaluation of several unlined pressure shafts and tunnels with insignificant to large leakage, the authors suggest following classification category for leakage (Table 4).

\section{Conclusions}

Application of unlined pressure shaft and tunnel concept in Norway is almost 100 years old. The lessons learned from the partial failure at different projects built in the 1920s have been crucial in applying unlined pressure shaft and tunnel concept, which proved to be the most cost effective and stainable solutions in Norway. The experiences gained from over 200 unlined pressure shafts and tunnels built during 1950s, 6os and 70s made it possible to refine and upgrade the design criterion over the time. However, very little effort have been made to apply this innovative concept outside Scandinavia mainly due to pseudo understanding that the Scandinavian rock mass are the only one that can tolerate this kind of hydrostatic head as have been practiced here in Norway. In author's opinion, this is not the complete truth. In fact, many of the waterway systems in Norway run through the Caledonian mountain series where the rock types are as similar as for example in the lesser Himalayan and higher Himalayan rocks of the Himalayan Mountain. Similar may be the case in the Andes and other mountain series. However, what is important to be noted is that the tectonic history of all mountain range is not similar and therefore insitu stress conditions are quite different. Therefore, certain improvements are needed in the design criterion set here in Norway. A PhD research is underway at the Norwegian University of Science and Technology (NTNU), Norway with the aim to address applicability of unlined pressure tunnel concept in the Himalaya.

Dr. Krishna Kanta Panthi is an Associate Professor in Geological Engineering at the Department of Geology and Mineral Resources Engineering, Norwegian University of Science and Technology (NTNU), Norway, since 2008. He holds PhD degree in Rock Engineering, MSc in Hydropower Development and MSc in Tunneling. He is the author of many scientific papers published in renowned journals internationally. He has more than 20 years of experience in research, design and construction supervision of tunneling, hydropower and slope stability projects.

\section{Corresponding E-mail: krishna.panthi@ntnu.no}

Er. Chhatra Bahadur Basnet is conducting his PhD research at the Department of Geology and Mineral Resources Engineering, NTNU, Norway. He holds MSc degree in Hydropower Development from NTNU. He has more than six years of working experience in Planning, Design, and Construction Supervision of number of hydropower projects in Nepal.

\section{E-mail: chhatra.basnet@gmail.com}

\section{References}

Benson, R., 1989. Design of unlined and lined pressure tunnels. Tunnelling and Underground Space Technology, 4(2): 155-170.

Bergh-Christensen, J., 1975. Brudd i foret trykktunnel ved Åskåra kraftverk (Failure of unlined pressure tunnel at Åskåra Power Plant), Proc. Bergmekanikkdagen 1974. Tapir, Trondheim.

Broch, E., 1982. The development of unlined pressure shafts and tunnels in Norway, ISRM International Symposium. International Society for Rock Mechanics.

Broch, E., 1984. Unlined high pressure tunnels in areas 
of complex topography. International Water Power and Dam Construction, 36(11).

Broch, E., 2013. Underground hydropower projects Lessons learned in home country and from projects abroad, Norwegian Tunneling Society.

Buen, B., 1984. Documentation unlined water conduits in norway. Hard Rock Engineering, FHS, Oslo, Norway.

Buen, B. and Palmstrom, A., 1982. Design and Supervision of Unlined Hydro Power Shafts and Tunnels with Head up to 590 Meters, ISRM International Symposium. International Society for Rock Mechanics.

Johansen, T., 1984. Norwegian Tunneling. Hard Rock Engineering, FHS, Oslo, Norway.

NGI, 1972. Oversikt over norske uforede tunneler og sjakter med vanntrykk over $100 \mathrm{~m}$ samt enkelte andre med lavere trykk, Norwegian Geotechnical Institute, Oslo, Norway.

NVE, 1970. Byrte Kraftverk. Brudd i råsprengt trykksjakt, Norges Vassdrags og Elektrisitetsvesen, Norway.

Panthi, K.K., 2014. Norwegian Design Principle for High Pressure Tunnels and Shafts: Its Applicability in the
Himalaya. Hydro Nepal: Journal of Water, Energy and Environment, 14: 36-40.

Rathe, L., 1975. An innovation in surge chamber design. Water power and dam construction, 27: 244-246.

Selmer-Olsen, R., 1969. Experience with unlined pressure shafts in Norway, Proc. Int. Symposium On Large Permanent Underground Openings, Oslo.

Selmer-Olsen, R., 1974. Underground openings filled with high-pressure water or air. Bulletin of the International Association of Engineering GeologyBulletin de l'Association Internationale de Géologie de l'Ingénieur, 9(1): 91-95.

Selmer-Olsen, R., 1985. Experience gained from Unlined High Pressure Tunnels and Shafts in Hydroelectric Power Stations in Norway. Norwegian Soil and Rock Engineering Association, Publ(3).

Valstad, T., 1981. Uforete vanntunneler og -sjakter: vannutbrudd fra tilløpstunnelen til Bjerka kraftverk. Norges geotekniske institutt (NGI), Oslo, Norway.

Vogt, J.H.L., 1922. Trykktunneler og geologi (Pressure tunnels and geology). Report no. 93. Norges Geol. Undersøkelse, Oslo, Norway. 